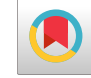

\title{
Human Embryonic Stem Cell Research: A Comparison Between Turkey and Iran
}

\author{
Tansu Sayar Kanyış ${ }^{1, *}$ \\ ${ }^{1}$ Department of Law, Izmir University of Economics, Izmir, Turkey \\ "Corresponding author: Department of Law, Izmir University of Economics, No. 156, Sakarya St. Balçova, Postal Code: 35330, Izmir, Turkey. Email: sayar.tansu@gmail.com
}

Received 2020 January 30; Revised 2020 February 15; Accepted 2020 February 16.

\begin{abstract}
The human embryo has a special character, with its ability to hold the personal data of both ova and sperm donors and its own, in addition to its potential to become a human being. For this reason, states should give the human embryo proper protection, which should be more rigorous than any somatic or germ cells of a human being. Legal protection provided by states reflects their view on the moral status of the human embryo. The moral status of the human embryo is gradual, but it is difficult to measure the stages of the human embryo's development since its development is a continuous process. It is possible to say that the 14-day rule, the early embryonic stage, transfer to the women's body, and ensoulment are accepted as important stages for human Embryonic Stem Cell Research (hESCR). According to Turkish regulations, it is not possible to do hESCR in Turkey. Iran gives permission to use spare/surplus embryos in hESCR based on fatwas, and regulates the conditions clearly in guidelines. Iran's regulations and practices are a reflection of the view that the human embryo has a gradual independent moral status. Graduality is provided by the stages of the 14-day rule, implantation into the womb, and ensoulment. However, in Turkey, although the gradual independent moral status view is seen in the regulations on abortion and assisted reproductive techniques, it is seen that regulations on hESCR are incompatible with other regulations on the practices concerning the human embryo. We believe that Turkey should permit hESCR, at least, on spare/surplus human embryos.
\end{abstract}

Keywords: Human Embryonic Stem Cell Research, Moral Status of Human Embryo, Law, Ethics, Iran, Turkey

\section{Context}

Human embryonic stem cell research is very important for finding new effective treatments for human diseases. Human embryonic stem cells contain pluripotent cells. Pluripotent cells have the potential to change into at least 200 types of somatic cells $(1,2)$. Scientists believe that embryonic stem cells will make it possible to treat very important diseases like Alzheimer's disease, diabetes, neurodegenerative defects, heart diseases, Parkinson's disease, and anemia $(1,2)$. However, the fact that human embryos are destroyed in human Embryonic Stem Cell Research (hESCR) causes intense disputes on the moral status of in vitro human embryos (3).

States that permit hESCR are obliged to provide proper protection to the human embryo. This obligation might be based on the International Treaties or fundamental principles and rights of law such as the principle of human dignity or right to respect personal autonomy and bodily integrity. States' obligations to provide proper protection to human embryos can cause different attitudes and large varieties in their hESCR legislations. Table 1 shows a variety of legislation in different states (supplementary file Appendix 1).

In this study, the views on the moral status of the human embryo will be explained, as the moral status is closely linked to the legal status of the human embryo. After that, the Islamic Republic of Iran's and Republic of Turkey's legal rules on hESCR will be clarified, as the two states' have much in common from a sociological perspective. In this way, the differences and similarities of the two states' regulations on hESCR and consequently, their views on the moral status of the human embryo will be determined.

\section{Moral Status of the Embryo}

The moral status of the embryo is linked to its legal status. In this part of the study, we will discuss how they are linked. According to Fleischman, Chervenak, and McCullough, the authors who consider the embryo as a living being with the potential to become a human being, the em- 


\begin{tabular}{lcc}
\hline Table 1. A Variety of hESCR Legislations in Different States \\
\hline & $\begin{array}{c}\text { Permits the Use of } \\
\text { Surplus Embryos in } \\
\text { hESCR }\end{array}$ & $\begin{array}{c}\text { Permits the Use of } \\
\text { Produced Embryos in } \\
\text { hESCR }\end{array}$ \\
\hline Turkey & - & - \\
\hline Iran & + & + \\
\hline Saudi Arabia & + & + \\
\hline Tunisia & - & - \\
\hline Italy & - & - \\
\hline Ireland & - & - \\
\hline UK & + & + \\
\hline Germany & + & - \\
\hline France & + & + \\
\hline USA & + & + \\
\hline S. Korea & + & - \\
\hline
\end{tabular}

bryo has a sui generis legal status. As regards this opinion, three views have revealed: "the view that the embryo has no moral status", "the view that the embryo has a gradual independent moral status", and "the view that the embryo has a moral status starting from its constitution" (4) (supplementary file Appendix 2).

According to the view that the embryo has no moral status, the embryo has no difference from the other body parts of the pregnant woman. Physicians, therefore, have no obligation to consider the interests of the embryo. As it is not possible to know the opinion of the embryo, the mother's consent is sufficient before any medical intervention. In this view, the embryo is a body part. It is possible to divide the body parts into two, interbody parts, and the body parts that are departed from the body. It is also possible to divide the body parts into two, somatic cells, and germ cells. When we talk about human embryonic stem cells, the target of the discussion is clearly an in vitro embryo. Thus, it is possible to say that such an embryo is a body part that is departed from the body. As we know, an embryo is neither a somatic cell nor a germ cell; we can, therefore, state that it must have better protection than both somatic cells and germ cells. If we explain the legal status of the body parts departed from the body, it may enlighten the in vitro embryos legal status, and if we explain the legal status of the germ cells, it may also enlighten the legal status of the embryo, by saying that the embryo should have more protection than germ cells have (4).

As the embryo has genotypes, and is a living being with the potential to be born and become a human being, it has a sui generis legal status and it is neither a property nor a person. However, the germ cells without such potential cannot enjoy such a special status (5). There are different opinions on whether an in vitro embryo is a property or not.

According to the dominant opinions of French, German, and Turkish doctrines, germ cells that are departed from the body cannot be considered as a property and giving harm to these cells causes a violation of personal rights. On the other hand, it is highly debated in the doctrine about whether personal rights are related to reproductive rights or bodily integrity (5). Also, some authors in the doctrine claim that it is possible to protect the germ cells with both property rights and personal rights; they also claim that it is better not to entitle them a property status if these cells will be used as a continuation tool of the donor's personality, with the help of new technologies (6) (supplementary file Appendix 3). In our opinion, giving extra protection derived from the donors' property rights does not mean that the germ cells are given the status of the property, which would decrease their value. On the contrary, giving the protection of both property and personal rights means that the germ cells are highly protected; so, they are very valuable. In conclusion according to our way of view, it is not disadvantageous to give the germ cells' protection of property rights besides the personal rights of their donors (supplementary file Appendix 4).

From the second view, the embryo has a gradual independent (supplementary file Appendix 5) moral status. For the supporters of this view, while the termination of pregnancy is easier in the early stages of pregnancy, it becomes more difficult later because the moral status of the embryo can increase the pregnancy progress. The supporters of this view accept that the embryo grows fast, so it is difficult to divide its development into stages; yet, they claim that such a division is a necessity (4). Within the attempt of determining the stages, many measures have been developed, such as dividing the pregnancy into trimesters (supplementary file Appendix 6), beginning of the heart beating (supplementary file Appendix 7), the ability of feeling pain (supplementary file Appendix 8), the ability of movement (supplementary file Appendix 9), viability (supplementary file Appendix 10), etc. One of these measures, and the one which is related to our topic of hESCR, is the early embryonic stage (7).

The early embryonic stage measure has affected the regulations on hESCR in many states, particularly the United Kingdom. The early embryonic stage of the embryo points to the first 14 days of its development. In this period, many cell cleavages happen, anlage comes out from the fallopian tube and it becomes a blastocyst and implants into the wall of the uterus. At the end of this stage of embryo development, its cells lose their totipotent characteristics, and become pluripotent cells with the ability to constitute variable tissues and organs of the body (8).

In the United Kingdom, the Human Fertilization and 
Embryology Act dated 1990 (9) regulates a time restriction for hESCR in Article 3 (4), stating that the embryo which is a target of research should be a maximum 14-days-old. As seen, the embryo of a maximum 14-days-old has less protection than older embryos because it can be a target of hESCR. It is certain that there is a difference between those two stages. However, the cause of the difference is not necessary to protect the embryo's interests; the main reason for using embryonic stem cells is being able to use totipotent and pluripotent cells. After the first 14 days, embryo's cells start to lose their pluripotent characteristics, which means they are no longer useful for such research. On the other hand, it is still possible to say that the regulation considers the stages of the embryo by paying regard to the fact that while the characteristics of embryo's cells are transferring from totipotent and pluripotent to somatic and germ cells, the embryo more closely resembles a human being (10).

While considering the early embryonic stage, the situations of in vitro and in vivo embryos have differences, especially in the subject of hESCR. The status of an in vivo embryo is not based on the way it was created. There is no difference that depends on whether it is constituted in normal ways or it is fertilized in vitro for IVF treatment and then transferred to the mother's womb. However, before being transferred into the mother's womb, the moral status of in vitro and in vivo embryos is different. In some states such as the United Kingdom and Iran, if an in vitro embryo will not be used for IVF, it may be the subject of hESCR. The transfer into the womb can, therefore, be considered as a sub-measure in the early embryonic stage measure (supplementary file Appendix 11).

The third view on the moral status of the embryo is that the embryo has a moral status since its constitution. The supporters of this view base the moral status of the embryo on philosophical and religious views (4). The views that claim there is a connection between the moment of gaining personality and existence have tried to make explanations on the meaning of existence and its reflection on the human embryo. In this meaning, two explanations have been made. The first explanation claims that existence means being fully constructed and the second explanation claims that existence means having the potential to exist. In the doctrine, while the explanation of potentiality dominates, it is seen that both explanations are used together. According to some authors in the doctrine, the potential of existing is not a passive potential. The potentiality of development means the development itself, and for the embryo, it starts at the moment of the activation of the DNA. From that moment on, the embryo will continue developing. From this view, the termination of pregnancy is possible only when it saves the pregnant woman's life.
For nonfatal fetal anomalies, the termination of pregnancy should be forbidden, but for fatal fetal anomalies, the termination is allowed, as the embryo will inevitably die (7). As seen, according to this view, it is not possible to divide the development of the embryo into stages. An embryo is an individual, who has personality, starting from the moment of fertilization. Thus, from this point of view, it is not possible to allow hESCR.

\section{3. hESCR in Turkish Legal System}

According to Article 90 (5) of the Turkish Constitution, laws, by-laws, and other legislation types below the hierarchy of norms cannot conflict with international treaties on fundamental rights and freedoms. For this reason, the Convention for the Protection of Human Rights and Dignity of the Human Being with regard to the Application of Biology and Medicine: Convention on Human Rights and Biomedicine (supplementary file Appendix 12)(Oviedo Convention) is important for Turkish domestic law. The issue of hESCR is regulated by Article 18 of the Oviedo Convention. According to Article 18 of the Oviedo Convention, it is possible for a state party to allow research on in vitro embryos. Such a state should give adequate protection for the embryo. However, it is prohibited to create human embryos for "research purposes" (supplementary file Appendix 13 and Appendix 14). Regulation raises two issues. The first is over "adequate protection" and the second is "research purposes". In the doctrine, the "adequate protection" clause is explained as a measure of restriction for scientific research on the embryo. In this meaning, scientific research on human embryos should be unarbitrary in accordance with human dignity and with respect to the embryo. It is possible to say that the clause of "adequate protection" regulates an abstract rule. It gives the state parties a wide power of discretion on how to protect in vitro embryos. Because the explanation of the doctrine is more abstract than the concept itself, it is difficult to explain the concepts of "nonarbitrary" and "human dignity" (11).

It is possible to interpret the concept of "nonarbitrary" considering the regulation that prohibits creating human embryos for research purposes. We can say that the term "nonarbitrary" characterizes scientific research and warns that it is prohibited to make scientific research on the embryo if the scientific research has no therapeutic aim, such as finding a treatment for a disease or applying such a treatment. Also, the concept of "human dignity" can be similarly understood. Although it is discussed that the human embryo has human dignity, it is certain that individuals who research on human embryos have human dignity, and therefore have the obligation to act in accordance with 
human dignity. In our opinion, scientific research on embryos in accordance with human dignity means that the target of scientific research should be to find, develop, or apply a cure for serious human diseases. In this meaning, it is necessary to put some reasonable restrictions on scientific research to enable the prevention of treating human beings as objects and accordingly, ensure that hESCR is in accordance with human dignity (supplementary file Appendix 15).

Turkish domestic regulations are compatible with the Oviedo Convention. The Turkish Ministry of Health has issued a circular in 2005 on Embryonic Stem Cell Research. According to this circular, until the ethical and legal studies of the Ministry are completed, no embryonic stem cell research will be executed (supplementary file Appendix 16). After the circular dated 2005, the Ministry of Health issued another circular in May 2006 on Stem Cell Research to regulate how to use stem cells that are not embryonic stem cells in clinical research (supplementary file Appendix 17).

Interpreting the Circulars dated 2005 and May 2006 together caused different opinions in the Turkish doctrine. Some authors claimed that the two circulars are on different issues. While the Circular dated 2005 regulates embryonic stem cell research and prohibits them for an unknown duration, the Circular dated May 2006 lays down some main rules about non-embryonic stem cell research. Some other authors claimed that there is no restriction on embryonic stem cell research because while the circular dated 2006 provides some rules for stem cell research, it makes no mention of the embryonic stem cell research (12). We agree on the first opinion, because from our point of view, it fits the logic of the law, and reflects the meanings of the circulars. Indeed, in practice, there has been no embryonic stem cell research since the circular dated 2005 was issued (12-14).

The issue dated 2005 is criticized in the doctrine because it does not mention the therapeutic use of stem cells. As mentioned above, the Oviedo Convention forbids creating embryos for only scientific purposes but it does not forbid creating embryos for therapeutic reasons. The Oviedo Convention also does not forbid the interventions with therapeutic reasons on the human embryo. According to the principle of legality, if there is no legally determined prohibition and sanction for an act, there is liberty for doing the act (15). Neither Article 18/2 of the Oviedo Convention nor the Issue dated 2005 regulates and prohibits the interventions on the human embryo with the purpose of harvesting embryonic stem cells for therapeutic reasons. While it is possible, therefore, to claim that Turkish Law allows hESCR, both with human embryos created for therapeutic reasons and with surplus embryos, further investigation into Turkish legislation reveals that this claim is mistaken.

These two circulars of the Turkish Ministry of Health are criticized in the Turkish doctrine. According to the Turkish doctrine, the matter of hESCRis closely related to human rights and human dignity. For this reason, such a matter should not be regulated with a circular by the ministry, but with laws. Additionally, the circulars cannot remove the uncertainty over the matter $(12,16)$. Indeed, there is no specific law about hESCR in Turkey. For this reason, authors in the doctrine are just making interpretations by considering some other legislations on the related subjects, such as tissue and organ transplanting, experimentations on human beings, or IVF. While the legislations concern hESCR only when the human embryo is transplanted from or to a human being, legislation on IVF gives more guidance on whether hESCR is forbidden in Turkey or not.

According to the Article 22 of the Oviedo Convention, "When in the course of intervention any part of a human body is removed, it may be stored and used for a purpose other than that for which it was removed, only if this is done in conformity with appropriate information and consent procedures". This means that informed consent from the prospective mother and father is needed for the collection of ova and sperms, for determining for which purpose they will be used, and how they will be stored in an IVF clinic. Concordantly, Article 15/4 of the Regulation on Assisted Reproduction Techniques and Clinics (Regulation) points to which informed consent form will be used. According to this article, informed consent is needed for the storage, thaw, and destruction of embryos, ova, and sperms. Also, in Article 18/4 of the same Regulation, it is specified that ova and sperms taken from the spouses and the embryos constituted from these ova and sperms cannot be stored, used, transferred or sold for purposes other than those described in the Regulation. And finally, Article 18/12 of the same Regulation mentions the destruction of the embryos that will not be transferred to the mother in the future. As seen, although the regulation does not directly say that making research on surplus embryos is prohibited, it closes all the ways to making research on surplus embryos.

The prohibition of having embryonic stem cells from surplus embryos in the Turkish Legal System has been criticized in the doctrine. It is not seen logical that, while storage and destruction of embryos are permitted, it is prohibited to use them for hESCR (17-19). In our opinion, such legalizations do not serve the protection of the embryos, too. Yet, in assisted reproductive treatments, surplus embryos are already available, and if not be used for IVF, will certainly be destroyed. A system that legalizes the destruction of surplus embryos but prohibits using them for therapeutic purposes is neither protecting human embryos nor 
helping patients seeking treatment. In our opinion, the Turkish legal system needs a law that permits hESCR for therapeutic reasons in certain circumstances (supplementary file Appendix 18).

\section{4. hESCR in Iran}

In Iran, ethical rules consist of fatwas, national laws or ethics codes, and international guidelines (20). Iran's Supreme Leader Ayatollah Khamenei issued a fatwa on hESCR in 2002. In the Fatwa, he declared that hESCR is not conflicting with Shia tradition and congratulated the scientists who had produced hESC lines (3). This fatwa has enabled new fatwas, practices, and legislations that allow hESCR. After the first fatwa, Iran, the first Muslim state to allow hESCR, rapidly progressed in this branch of medical science. According to Ayatollah Khamenei, hESCR helps scientists to develop new therapeutic technologies for the benefit of the whole of humanity, and enables Iran to reach its goal of becoming a leading scientific nation in the Middle East $(3,21,22)$. However, according to Ayatollah Khamenei, reproductive cloning is prohibited. Although it is possible to destruct spare embryos for hESCR, and produce identical parts of human beings, research on human embryos should not lead to the production of a human being as a whole (3) (supplementary file Appendix 19).

Iran's Ministry of Health and Medical Education (MOHME) took a major step in 2000 for Iran to have a National Code of Ethics in Biomedical Research and has taken religion, law, ethics, and medical experts together. These experts have prepared a draft under the supervision of the Medical Ethics and Medical History Research Centre of Tehran University of Medical Sciences. In 2005, the Policymaking Council of MOHME successfully completed the review, and guidelines came into force (20). "Ethical Guide to Gamete and Embryo Research in the Islamic Republic of Iran" and "Ethical Guide to Stem Cell Research in the Islamic Republic of Iran” play an important role in our study.

The first chapter of the "Ethical Guide to Gamete and Embryo Research in the Islamic Republic of Iran" (supplementary file Appendix 20) has the title of human dignity. According to Article 1, human gametes and embryos can be used for therapeutic research only when it aims to cure human diseases. Article 2 strictly forbids the purchase and sale of human gametes and embryos (supplementary file Appendix 21). Article 3 prohibits the production of human embryos for research purposes. Research on embryos is acceptable in surplus embryos only when they are not certainly be used for IVF in the future (supplementary file Appendix 22). However, the same article allows an exception to the prohibition of the production of human embryos for research purposes. According to this exception, the production of an embryo is allowed if there is no surplus human embryo that has the necessary stem cell for such therapeutic research, and research on a human embryo is essential. Article 4 regulates that research on human embryos is permitted until the 14th day starting from fertilization. As seen, in the pre-ensoulment stage, it is possible to perform hESCR with both spare/surplus embryos and embryos created for therapeutic research (supplementary file Appendix 23).

In Article 6, it is regulated that the number of embryos used for research should be as few as possible. With this Article, Iran has not regulated a restriction of numbers. This is logical because every research has its own requirements. However, the Article warns the researchers to minimize the number of embryos used in research, in order to provide protection to human embryos. Also, Article 7 aims to provide protection for human embryos and specifies other restrictions for hESCR, such as the prohibition of producing chimeras and changing the genetic content of the gametes or embryos for transfer to the uterus, except for the purpose of preventing a specific illness. In our opinion, such restrictions protect human embryos from research incompatible with human dignity. It is clear that Iran provides those restrictions for the same reason by regulating them in the section on human dignity.

The second chapter of the Ethical Guide to Gamete and Embryo Research in the Islamic Republic of Iran is about taking consent from donors and permission from the Ethics Committee. According to Article 8, it is not possible to use a human embryo in research without donors' consent. A human embryo has the personal data of the sperm donor, ova donor, and the human-being if it realizes this potential. For this reason, the donors, whose personal data will be used in research, should be asked for their approval. Human embryos are not only holders of personal data. As mentioned before, they are also body pieces derived from donors. Patients' informed consent is a necessity for every medical treatment, and should be taken before starting treatment. However, for some medical treatments, the tissues and organs taken for the treatment can be used for different purposes; for such reasons and ways of use that appear later, informed consent should seek again. Article 8 mentions the necessity of taking informed consent. Article 9 also regulates that any research on human embryos requires the consent of embryo owners, and also the permission of the Ethics Committee. The articles 10,11, and 12 regulate how informed consent should be taken (supplementary file Appendix 24).

"Ethical Guide to Stem Cell Research in the Islamic Republic of Iran" emphasizes informed consent, too. According to article 5, before the donation of gametes, the donor 
should give informed and free consent in order to allow the embryo to be used for hESCR. The guideline also highlights that informed consent should be objective, and ensure that other treatments should not be done for providing new stem cells for research. For this reason, Article 6 says that the physician who provides infertility treatment and derives surplus embryos from the treatment cannot be the same researcher individual who uses stem cells for research and treatment. Also, Article 7 says that the physician who makes the abortion decision should be completely independent of the group that conducts stem cell research. With articles 6 and 7, the legislator wants to be sure that researchers are using only surplus embryos, and not creating embryos for stem cell research. These two articles may help the misuse of other treatments such as abortion and IVF, for deriving more human embryos or stem cells.

As seen, Iran's practice in hESCR is based on fatwas and guidelines, rather than parliamentary legislation. This situation is criticized in the doctrine. According to some views, the reason for Iran's hESCR policy being apparently so open-minded is that the fatwas do not emerge out of the public and secular debate (3). Guidelines are also criticized for the reason that they are still open to public debate and examination (22). Yet, it is still valuable because a medical practice that is allowed by the state has some ethical restrictions for the protection of human dignity.

Although the guidelines seem clear, it is possible to notice some confusion between researchers. According to Saniei's study, while some researchers, for example, an embryologist, claim that creating embryos for research for therapeutic purposes is forbidden, others, for instant an Ethics Committee member, claim that there is no prohibition in hESCR (3). When the guidelines are considered, it is possible to say that both claims are mistaken. As mentioned before, according to the guidelines, it is prohibited to create human embryos for research purposes alone; however, for exceptional cases, it is possible to create human embryos for therapeutic research. It is also clearly stated under which circumstances such an exceptional case occurs: the research should have a therapeutic purpose; for research to reach its purpose, it should be necessary to do the research on a human embryonic stem cell, and the required human embryonic stem cell should not be found in the spare/surplus embryos. It is also possible to state that the Ethics Committee should decide whether or not these exceptional circumstances occur in the case. From our point of view, the reason for the confusion is the inability to distinguish the concept of "therapeutic cloning" from the concepts of "reproductive cloning" and "only research purposes". Article 18 of the Oviedo Convention leads to a similar confusion in both Turkey and most other party states of the Convention. In my opinion, it is not enough to make regulations; researchers should be clearly informed by legal-ethical training about the limits.

\section{Discussion}

The human embryo has a special character, because it holds the personal data of both ova and sperm donors and its own, and also the potential to become a human being. For this reason, states should give the human embryo proper protection beyond that of any human somatic or germ cell. To give proper protection to hESC, states have legalized the protection of human embryos by procuring the personal autonomy of sperm and ova donors in the case of hESCR or parents in the case of abortion. States have legalized the protection of human embryos by putting legalethical restrictions on sperm and ova donors' or parents' personal autonomy. These protections provide human embryos with a moral status above that of any property or human somatic or germ cells whether in a part of or departed from the human body, but below that of a human being that has legal personality. However, it is also seen that the moral status of the human embryo is gradual; its moral status is lower in the first stages of its development, and higher in the further stages. The staging of the human embryo's development is difficult, since the development is a continuous process. It is possible to say that the 14-day rule, the early embryonic stage, transfer to the women's body, and ensoulment are accepted as important stages for hESCR.

In this study, we examined legislations on hESCR in the Islamic Republic of Iran and the Republic of Turkey, as they have much in common from a sociological perspective. As a result, it is seen that neither states have regulated the subject with parliamentary legislation, as Turkey regulates it with the Ministry of Health Circulars and Iran with fatwas and ethical guidelines. Both states have been criticized in their doctrines because the subject of hESCR should be legalized with acts of their parliaments, as the subject is important for human dignity and bodily integrity, and needs public debate.

Another result of the study is that Iran and Turkey are very different on the issue of allowing for hESCR. Turkish legalizations do not openly prohibit therapeutic hESCR; however, they prohibit every practice that is not legally permitted and creating human embryos for therapeutic hESCR and using spare/surplus embryos for hESCR are not counted in the practices that are permitted. However, Iran clearly gives permission in the guidelines for the use of spare/surplus embryos in therapeutic hESCR. Additionally, in the exceptional cases that the research has a therapeutic purpose, there is a necessity of doing the research on hESC 
for the research to reach its purpose, and the impossibility of finding the required human embryonic stem cell in the spare/surplus embryos, it is permitted to create human embryos for therapeutic hESCR.

These permissions in Iran are compatible with the legalizations on abortion and assisted reproductive techniques. Permitting hESCR on spare/surplus embryos is compatible with the regulations on abortion because they both result in the destruction of the human embryo and both are based on the rule of ensoulment. Permitting hESCR on spare/surplus embryos is compatible with the regulations on assisted reproductive techniques because spare/surplus embryos will inevitably be destructed, and destructing them in the attempt to find new treatments for patients is logical. However, in Turkey, terminating a pregnancy both before and after the ensoulment is possible for specific reasons, assisted reproductive techniques that bring spare/surplus human embryos are practiced, and the destruction of the spare/surplus embryos is an obligation, but it is forbidden to use these embryos for therapeutic hESCR.

Keeping the number of destructed human embryos to the minimum is a necessity for human dignity and a result of the special moral status of the embryo. Iran's regulations and practices on hESCR, abortion, and assisted reproductive techniques are compatible with each other. These regulations are a reflection of the view of the human embryo that has a gradual independent moral status. Graduality is provided by the stages of the 14-day rule, implantation into the womb, and ensoulment. However, in Turkey, while the gradual independent moral status view is seen in the regulations on abortion and assisted reproductive techniques, regulations on hESCR are incompatible with other regulations on practices concerning the human embryo. Thus, from our point of view, hESCR should be permitted, at least, on spare/surplus human embryos.

\subsection{Conclusions}

Iran clearly gives permission in its guidelines for the use of spare/surplus embryos in the therapeutic hESCR. Additionally, in the exceptional cases that research has a therapeutic purpose, there is a necessity of doing research on hESC for research to reach its purpose, and the impossibility of finding the required human embryonic stem cell in the spare/surplus embryos, it is permitted to create human embryos for therapeutic hESCR. These regulations are a reflection of Iran's view of the human embryo that has a gradual independent moral status.

Turkish legalizations do not openly prohibit therapeutic hESCR. However, they prohibit every practice that is not legally permitted and creating human embryos for therapeutic hESCR and using spare/surplus embryos for hESCR are not counted in the permitted practices. Turkey's regulations on abortion and assisted reproductive techniques are a reflection of the view that the human embryo has a gradual independent moral status. However, Turkey's attitude toward preventing hESCR conflicts with this view. Besides, this confliction is not serving the obligation of providing proper protection for human embryos since human embryos are already being destructed in assisted reproductive techniques in Turkey. From our point of view, hESCR should be permitted, at least, on spare/surplus human embryos.

\section{Supplementary Material}

Supplementary material(s) is available here [To read supplementary materials, please refer to the journal website and open PDF/HTML].

\section{Footnotes}

Conflict of Interests: The study has no potential conflict of interest.

Funding/Support: Author received no financial support or funding for the study.

\section{References}

1. Sadler TW. Langman's medical embryology. International ed. Wolters Kluwer; 2015.

2. Robertson JA. Ethics and policy in embryonic stem cell research. Kennedy Inst Ethics J. 1999;9(2):109-36. doi: 10.1353/ken.1999.0013. [PubMed: 11660628].

3. Saniei M. Human embryonic stem cell science and policy: The case of Iran. Soc Sci Med. 2013;98:345-50. doi: 10.1016/j.socscimed.2013.10.028. [PubMed: 24230960]. [PubMed Central: PMC3988836].

4. Fleischman AR, Chervenak FA, McCullough LB. The physician's moral obligations to the pregnant woman, the fetus, and the child. Semin Perinatol.1998;22(3):184-8. doi:10.1016/s0146-0005(98)80033-5.

5. Ozbilen $\mathrm{AB}$. [Legal transactions related to human biological substances]. Istanbul: Vedat Kitapcilik; 2011. Turkish.

6. Oguzman MK, Selici O, Oktay-Ozdemir S. [Property law].17 ed. Istanbul: Filiz Kitabevi; 2014. Turkish.

7. Stith R. Why pro-life arguments sound absurd. Hum Life Rev. 2007;33(1):23-6.

8. Lazar RP. Considerations regarding the legal status of embryo and fetus from the perspective of the right to life. Contemp Read Law Soc Justice. 2012;4(1):371-82.

9. United Kingdom. Human fertilization and embryology act. 1990, [cited 26 Dec. 2019]. Available from: http://www.legislation.gov.uk/ukpga/ $1990 / 37 /$ contents.

10. Hillebrand I, Stöcke-Jochmus F, Holz AS. Stem cell research. 2004, [cited 1 Jan. 2016]. Available from: http://www.drze.de/in-focus/stem-cellresearch/laws-and-regulations.

11. Tugrul K. [Council of Europe human rights and biomedicine convention]. Ankara Univ Facul Law J. 2006;55(1):1. Turkish. doi: 10.1501/Hukfak_0000000363. 
12. Hakeri H. [Medical law]. 10 ed. Ankara: Seckin Publishing; 2015. Turkish.

13. Arda B, Aciduman A. An evaluation regarding the current situation of stem cell studies in Turkey. Stem Cell Rev Rep. 2009;5(2):130-4. doi: 10.1007/s12015-009-9072-2. [PubMed: 19521803].

14. Candan ZN, Kahraman S. Establishment and characterization of human embryonic stem cell lines, Turkey perspectives. In Vitro Cell Dev Biol Anim. 2010;46(3-4):345-55. doi: 10.1007/s11626-010-9299-x. [PubMed: 20349214].

15. Centel N, Zafer H, Cakmut O. [Introduction to Turkish criminal law]. 6 ed. Istanbul: Beta Publishing; 2010. Turkish.

16. Erdal Y. [The place of cloning (copying) in criminal law]. J Ankara Univ Facul Law. 2014;63(3):643-85. Turkish. doi: 10.1501/Hukfak_0000001762.

17. Karakaya A. [Stem cell studies and ethics: Ethical issues in the work made on stem cells obtained from human embryos in Turkey] [dissertation]. Is- tanbul: Department of Civilization Studies, Institute of Social Sciences, Fatih Sultan Mehmet Vakif University; 2013. Turkish.

18. Sayar T, Hizal SA. [Human cloning with its ethical and legal dimensions]. Ankara: Forensic Scientists Association, National Health Law Congress. Seckin Publishing; 2016. Turkish.

19. Ozturk A. [Legal responsibility arising from assisted reproductive treatment methods]. Istanbul: Legal Publishing; 2014. Turkish.

20. Zahedi F, Larijani B. National bioethical legislation and guidelines for biomedical research in the Islamic Republic of Iran. Bull World Health Organ. 2008;86:630-4.

21. Schienberg J, Katz N. Iran: The stem cell fatwa science and religion's unlikely union. 2009, [cited 28 Jan. 2020]. Available from: https://www. pbs.org/frontlineworld/rough/2009/06/iran_stem_cell.html.

22. Saniei M, De Vries R. Embryonic stem cell research in Iran: Status and ethics. Indian J Med Ethics. 2008;5(4):181-4. doi: 10.20529/IJME.2008.067. [PubMed:18988380]. 